\title{
Quercetin Suppresses Proliferation of Liver Cancer Cell Lines In Vitro
}

\author{
TORU HISAKA ${ }^{1}$, HISAMUNE SAKAI ${ }^{1}$, TOSHIHIRO SATO ${ }^{1}$, YUICHI GOTO ${ }^{1}$, YORIKO NOMURA ${ }^{1}$, \\ SHOGO FUKUTOMI ${ }^{1}$, FUMIHIKO FUJITA ${ }^{1}$, TOMOAKI MIZOBE ${ }^{1}$, OSAMU NAKASHIMA ${ }^{2}$, \\ MASAHIKO TANIGAWA ${ }^{3,4}$, YOSHIKI NAITO ${ }^{3}$, JUN AKIBA ${ }^{3}$, SACHIKO OGASAWARA ${ }^{4}$, \\ KOUTA NAKASHIMA ${ }^{4}$, YOSHITO AKAGI ${ }^{1}$, KOJI OKUDA ${ }^{1}$ and HIROHISA YANO ${ }^{4}$ \\ Departments of ${ }^{1}$ Surgery and ${ }^{4}$ Pathology, Faculty of Medicine, Kurume University, Kurume, Japan; \\ ${ }^{2}$ Department of Clinical Laboratory Medicine and ${ }^{3}$ Department of Diagnostic Pathology, \\ Kurume University Hospital, Kurume, Japan
}

\begin{abstract}
Background/Aim: We investigated the antiproliferative effect of quercetin on liver cancer cell lines. Materials and Methods: Thirteen liver cancer cell lines were cultured followed by treatment with varying concentrations of quercetin $(0-100 \mu \mathrm{M})$ or quercetin and 5-FU, and the cell viability was analysed by the MTT assay. Flow cytometry was also used to examine cell cycle progression after treatment with quercetin. Results: The addition of quercetin resulted in a dose- and time-dependent suppression of cell proliferation. In some cell lines, treatment with quercetin and 5-FU caused an additional or synergistic effect. Most cell lines displayed cell cycle arrest at different phases of the cell cycle. Conclusion: Quercetin inhibits the proliferation of liver cancer cells via induction of apoptosis and cell cycle arrest.
\end{abstract}

Hepatocellular carcinoma (HCC) is the most frequent primary cancer, and an important medical problem (1). Many HCC patients have a history of chronic hepatitis or liver cirrhosis caused by Hepatitis B virus (HBV) or Hepatitis C virus (HCV) infection (2-4). Treatments for poor liver function associated with hepatitis are limited and outcomes are poor. Even with the most successful treatments, the 5year recurrence rate of HCC is very high (1). Treating and preventing recurrence is critical for improving survival rates.

Quercetin is a type of flavonoid contained in many plants, and possesses antioxidant, anti-inflammatory, and immuno-

This article is freely accessible online.

Correspondence to: Toru Hisaka, MD, Ph.D., Department of Surgery, Faculty of Medicine, Kurume University, 67 Asahi-machi, Kurume, Fukuoka 830-0011, Japan. Tel +81 942317566, Fax: +81 942340709, e-mail: thisaka@med.kurume-u.ac.jp

Key Words: Quercetin, antiproliferation effect, apoptosis, hepatocellular carcinoma. logical capabilities (5). Quercetin can suppress cell proliferation and induce apoptosis in human cancers, including breast, lung, oral, and prostate; however, there is no report on its effect on liver cancer (6-9). In the current study, we examined the antitumor effects of quercetin on $13 \mathrm{HCC}$ cell lines in vitro.

\section{Materials and Methods}

Cell lines and cell culture. This study utilized 11 HCC cell lines (KIM-1, KYN-1, KYN-2, KYN-3, HAK-1A, HAK-1B, HAK-2, HAK-3, HAK-4, HAK-5, and HAK-6), and 2 human combined hepatocellular and cholangiocarcinoma $(\mathrm{CHC})$ cell lines $(\mathrm{KMCH}-1$ and $\mathrm{KMCH}-2$ ). The cell lines were originally established in the Department of Pathology, Kurume University Faculty of Medicine, and each of them retains the morphological and functional features of the original tumor as previously described (10-18). Each cell line was grown in Dulbecco's modified Eagle medium (Nissui Seiyaku, Co., Japan) supplemented with $2.5 \%$ heat-inactivated $\left(56^{\circ} \mathrm{C}, 30\right.$ min) fetal bovine serum (Bioserum, Victoria, Australia), $100 \mathrm{U} / \mathrm{ml}$ penicillin, $100 \mu \mathrm{g} / \mathrm{ml}$ streptomycin (GIBCO BRL/Life Technologies, Inc., Gaithersburg, MD, USA) and $12 \mathrm{mmol} / \mathrm{l}$ sodium bicarbonate, in a $5 \% \mathrm{CO}_{2}$ humidified atmosphere at $37^{\circ} \mathrm{C}$.

Effects of quercetin on the proliferation of hepatocellular carcinoma and combined hepatocellular and cholangiocarcinoma cell lines in vitro. The effects of quercetin with and without $5-\mathrm{FU}$ on proliferation were examined using 3-(4,5-dimethylthiazol-2yl-yl)-2,5-diphenyl tetrazolium bromide (MTT) assay kit (Chemicon, Temecula, CA, USA) as previously described (10). Quercetin was obtained from Sigma Chemical, and 5-fluorouracil (5-FU) was purchased from

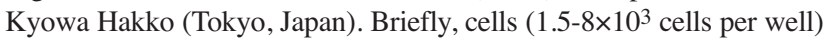
were seeded on 96-well plates (Falcon, Becton Dickinson Labware, Tokyo, Japan), cultured for $24 \mathrm{~h}$, and then culture medium was replaced with a new one containing quercetin $(0,12.5,25,50,100$ $\mu \mathrm{M})$ with or without 5 -FU $(0,10,100 \mu \mathrm{M})$. After treatment of cells for 24,48 or $72 \mathrm{~h}$, the number of viable cells was examined.

Quantitative analysis of apoptosis induced by quercetin in vitro. Cells cultured with or without quercetin for $72 \mathrm{~h}$ were stained with Annexin V-EGFP (enhanced green fluorescent protein) and analysed by using 


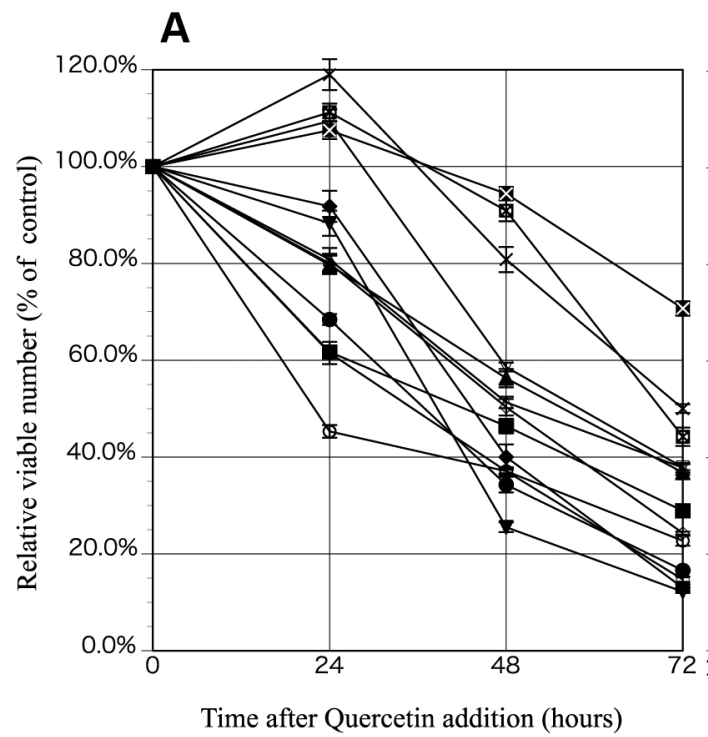

B

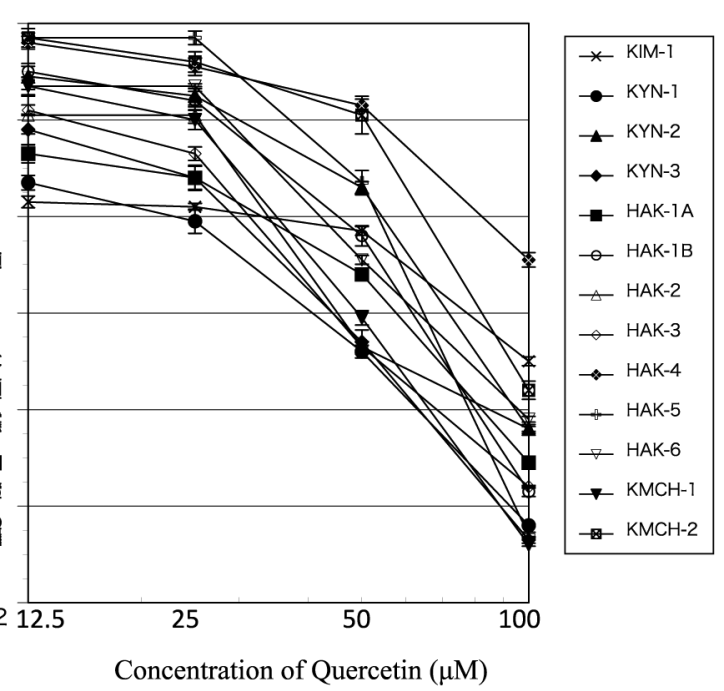

Figure 1. Effect of quercetin on the proliferation of liver cancer cell lines. (A) Relative viable cell number (\% of the control) was reduced in a timedependent manner after the addition of $100 \mu \mathrm{M}$ of quercetin. (B) $72 \mathrm{~h}$ after adding 12.5, 25, 50 or $100 \mu \mathrm{M}$ of quercetin cell proliferation was suppressed in a dose-dependent manner but in varying degrees. The suppression was statistically significant $(p<0.01-0.0001)$ in the range of 12.5 $100 \mu \mathrm{M}$ of quercetin in all cell lines. Eight samples were used in each experiment (n=8). The experiment was repeated at least three times for each cell line to confirm reproducibility of the data, and almost identical results were obtained. Error bar represents SE. Mean absorbance of the control cells (cells cultured without quercetin) was determined as 100\%, and the mean of the other groups was expressed as a ratio.

an Apoptosis detection kit (Medical and Biological Laboratories Co., Ltd. Nagoya, Japan) according to the manufacturer's protocol. After staining, the cells were analyzed using a FACScan (Becton Dickinson Immunocytometry Systems Franklin Lakes, NJ, USA), and annexin V-EGFP-positive apoptotic cell rate was determined.

Cell cycle analysis. Cell lines were cultured with or without quercetin ( 25 or $100 \mu \mathrm{M}$ ) for $48 \mathrm{~h}$, labeled with $10 \mu \mathrm{mol} / \mathrm{l} \mathrm{BrdU}$ for $30 \mathrm{~min}$, fixed in $70 \%$ cold ethanol at $4^{\circ} \mathrm{C}$ overnight, stained with anti-BrdU and propidium iodide (Sigma Chemical Co.), and analyzed using a FACScan. Staining was performed using the modified technique described elsewhere (19). Briefly, fixed cells were washed with PBS, subjected to double-strand DNA denaturation treatment with $2 \mathrm{~mol} / 1 \mathrm{HCl}$ at room temperature for $30 \mathrm{~min}$, neutralized with $0.1 \mathrm{~mol} / 1 \mathrm{Na}_{2} \mathrm{~B}_{4} \mathrm{O}_{7}$, washed twice with PBS containing 0.5\% Tween 20, and 0.5\% BSA (PBS-T), incubated for $30 \mathrm{~min}$ at room temperature with $20 \mu \mathrm{l}$ anti-BrdU antibody, and washed with PBS-T. Then, cells were incubated for $30 \mathrm{~min}$ at room temperature with $4 \mu \mathrm{l}$ fluorescein isothiocyanate-conjugated goat antimouse immunoglobulin, and washed with PBS-T. DNA was counterstained with $5 \mu \mathrm{g} / \mathrm{ml}$ of propidium iodide for at least $20 \mathrm{~min}$ before flow cytometric analysis. Percentage of cells in the $\mathrm{G}_{0} / \mathrm{G}_{1}, \mathrm{~S}$, and $\mathrm{G}_{2} / \mathrm{M}$ phases of the cell cycle was calculated from a dot or contour plot obtained after flow cytometric analyses of double-stained cells.

Statistics. Significance in differences was estimated by using the Student's t test (two-tailed).

\section{Results}

In all 13 cell lines, the viable cell number reduced to around 20 to $70 \%$, after $72 \mathrm{~h}$ of treatment with $100 \mu \mathrm{M}$ of quercetin.
Table I. Quantitative analysis of apoptosis induced by quercetin in 13 liver cancer cell lines.

\begin{tabular}{lcc}
\hline Cell line & Annexin V-EGFP-positive apoptotic cell rates (\%) \\
\cline { 2 - 3 } & Control & Quercetin \\
\hline KIM-1 & $9.11 \pm 0.8$ & $98.7 \pm 8.2^{*}$ \\
KYN-1 & $9.15 \pm 1.6$ & $62.8 \pm 6.7^{*}$ \\
KYN-2 & $8.84 \pm 1.2$ & $26.4 \pm 0.7^{*}$ \\
KYN-3 & $9.38 \pm 1.4$ & $27.6 \pm 0.8^{*}$ \\
HAK-1A & $9.48 \pm 0.7$ & $78.3 \pm 7.2^{*}$ \\
HAK-1B & $9.34 \pm 0.5$ & $87 \pm 8.2^{*}$ \\
HAK-2 & $9.73 \pm 1.5$ & $47.1 \pm 4.4^{*}$ \\
HAK-3 & $9.54 \pm 0.7$ & $19.1 \pm 1.1^{*}$ \\
HAK-4 & $9.72 \pm 0.8$ & $16.6 \pm .1 .3^{*}$ \\
HAK-5 & $9.48 \pm 1.0$ & $86.6 \pm 8.1^{*}$ \\
HAK-6 & $8.68 \pm 0.9$ & $29.3 \pm 2.8^{*}$ \\
KMCH-1 & $9.40 \pm 1.0$ & $32.3 \pm 3.7^{*}$ \\
KMCH-2 & $8.83 \pm 0.7$ & $30.9 \pm 2.5^{*}$ \\
\hline
\end{tabular}

Cells were cultured with or without $100 \mu \mathrm{M}$ quercetin. Apoptosis was measured by Annexin V-EGFP staining. Annexin V-EGFP-positive cells rates are given as average \pm SD. Five samples were used in each experiment. ${ }^{*} p<0.001 v s$. corresponding control value.

In four of the cell lines (KIM-1, HAK4, HAK-6, KMCH-1), the cell proliferation reached a plateau $24 \mathrm{~h}$ after quercetin addition, and there was a reduction in their relative viable cell numbers thereafter. In the other 9 cell lines, there were 
A

Quercetin (-)

Quercetin $(25 \mu \mathrm{M})$

Quercetin $(100 \mu \mathrm{M})$

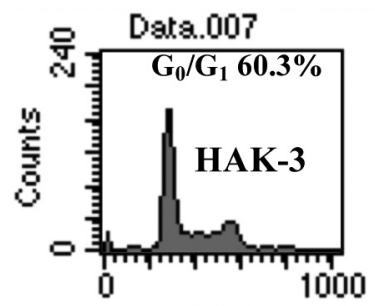

FL2-A
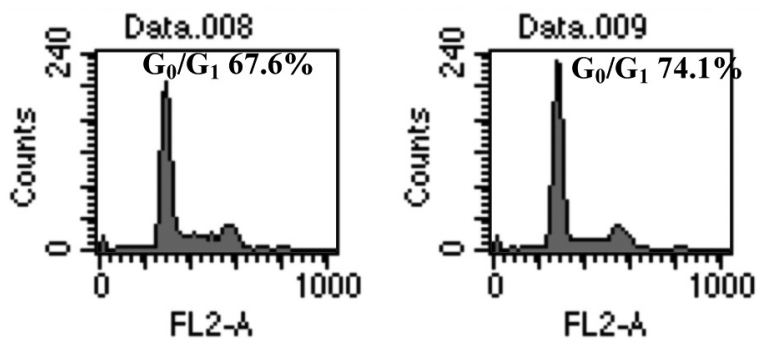

$\mathrm{G}_{0} / \mathrm{G}_{1}$ phase arrest cell lines: HAK-3,HAK-6, KMCH-1, KMCH-2.

B

Quercetin (-)

Quercetin $(25 \mu \mathrm{M})$

Quercetin $(100 \mu \mathrm{M})$
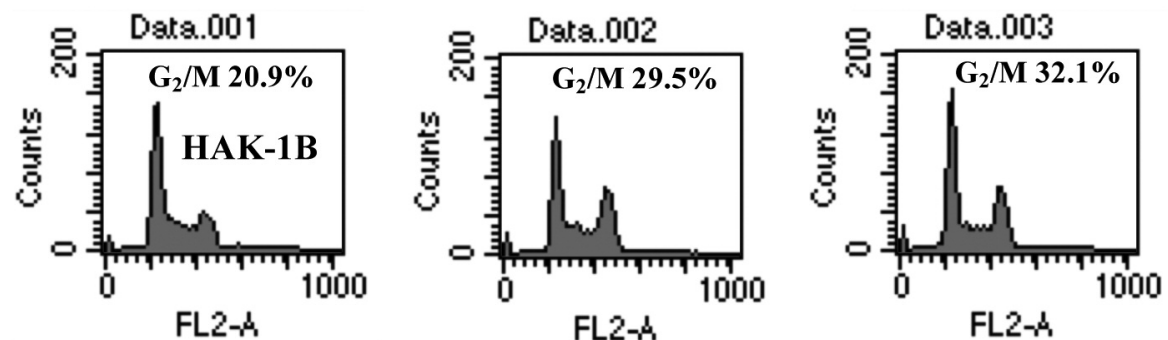

$\mathrm{G}_{2} / \mathrm{M}$ phase arrest cell lines: HAK-1B, KYN-2, KYN-3, HAK-2, HAK-4, HAK-5.

C

Quercetin (-)

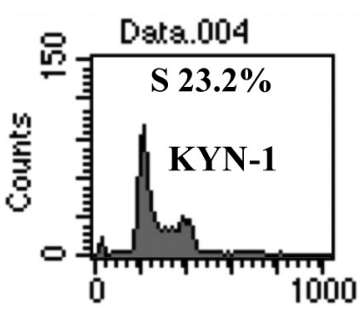

FL2-A
Quercetin $(25 \mu \mathrm{M})$

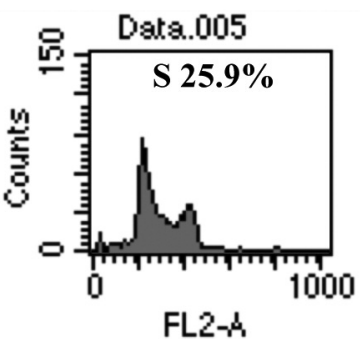

Quercetin $(100 \mu \mathrm{M})$

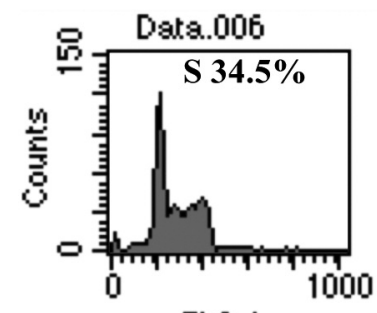

FL2-A

$S$ phase arrest cell lines: KIM-1, KYN-1.

Figure 2. Effect of quercetin on the cell cycle distribution of 13 liver cancer cell lines. Cells were treated with 0-100 $\mu \mathrm{M}$ quercetin for $48 \mathrm{~h}$ and analyzed by flow cytometry. Cell cycle distribution is shown as a histogram. Most liver cancer cell lines underwent cell cycle arrest, but the phase of arrest varied from cell line to cell line ( $A: G_{0} / G_{1}$ phase arrest, $B: G_{2} / M$ phase arrest, $C$ : $S$ phase arrest).

varying degrees of cell growth inhibition over the course of $72 \mathrm{~h}$ since quercetin addition (Figure 1A). All cell lines showed a dose-dependent decrease in the relative viable cell count $72 \mathrm{~h}$ after quercetin addition (Figure 1B). The relative viable cell count for cells cultured with $100 \mu \mathrm{M}$ of quercetin ranged between 12 to $70 \%$, with a mean of $31.4 \pm 17 \%$. In 10 cell lines (KYN-1, KYN-2, KYN-3, HAk-1A, HAK-1B, HAK-2, HAk-3, HAK5, HAK-6, KMCH-1, KMCH-2), the relative viable cell number reduced to below $50 \%$. Quantitative analysis of Annexin V-EGFP-positive apoptotic cells revealed that the appearance of apoptosis was significantly higher in the cells treated with quercetin compared to untreated cell lines (Table I).

We examined the effect of quercetin on the cell cycle of liver cancer cell lines. Cell cycle arrest was observed in 12 out of 13 cell lines. Following the addition of quercetin, a 


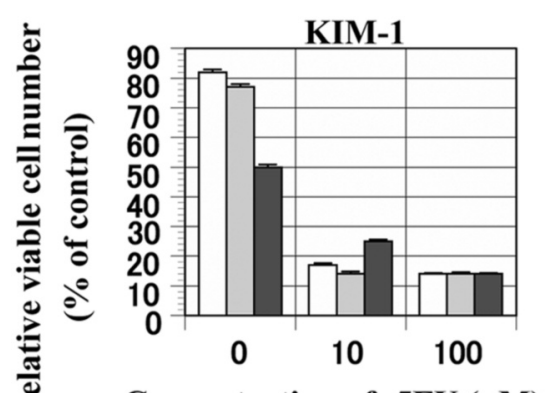

Concentration of -5FU $(\mu \mathrm{M})$

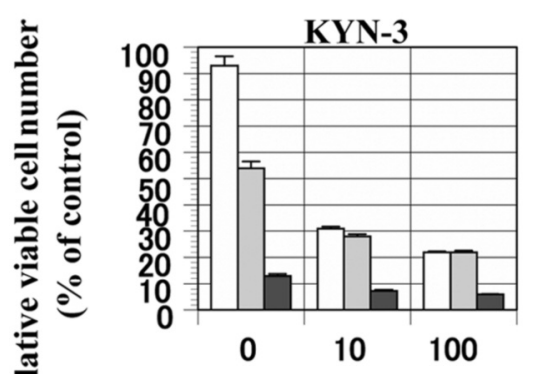

Concentration of $-5 F U(\mu \mathrm{M})$

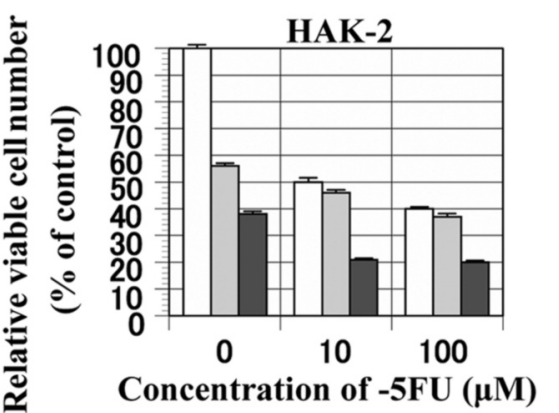

递

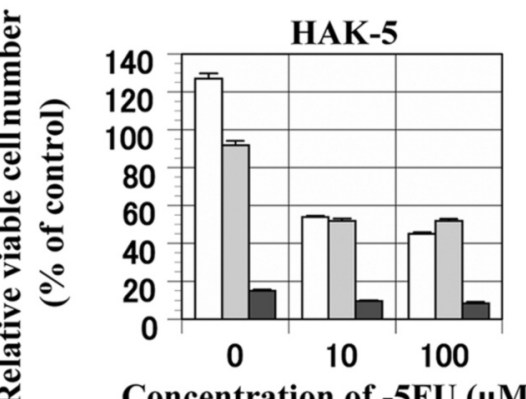

Concentration of $-5 \mathrm{FU}(\mu \mathrm{M})$

हัँ

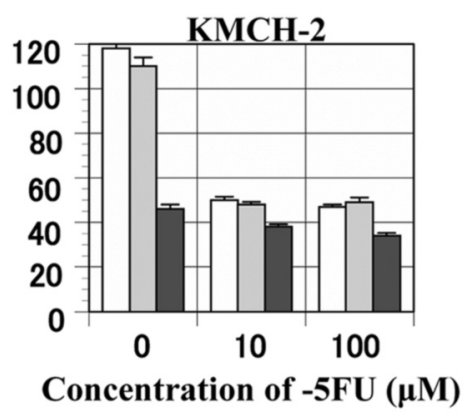

KYN-1

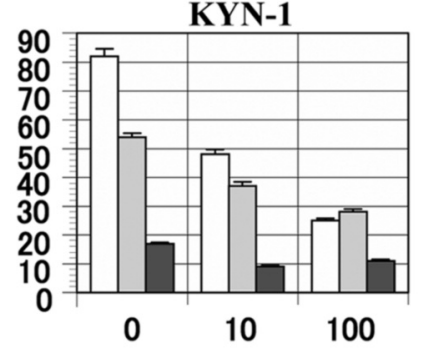

Concentration of $-5 \mathrm{FU}(\mu \mathrm{M})$

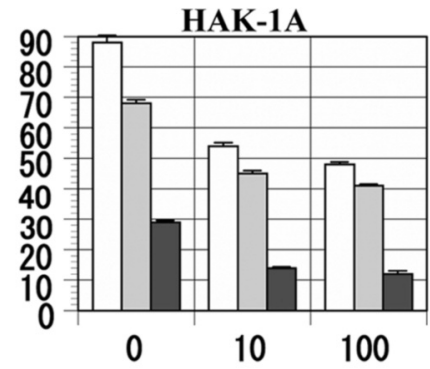

Concentration of -5FU $(\boldsymbol{\mu M})$

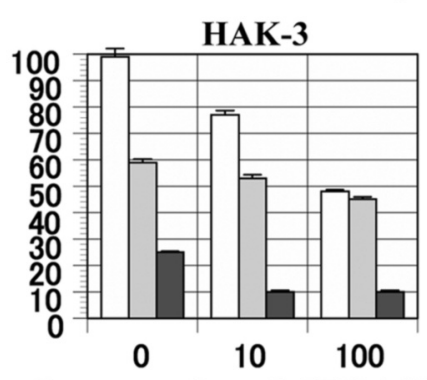

Concentration of $-5 \mathrm{FU}(\boldsymbol{\mu M})$

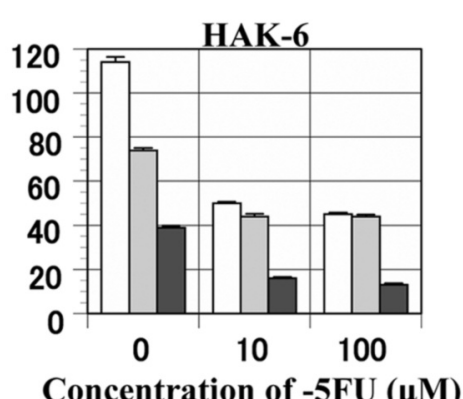

Concentration of $-5 \mathrm{FU}(\boldsymbol{\mu M})$

$\square$ Quercetin $25 \mu \mathrm{M}$

Quercetin $50 \mu \mathrm{M}$

Quercetin $100 \mu \mathrm{M}$

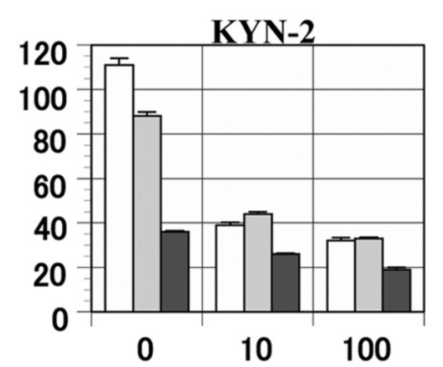

Concentration of $-5 \mathrm{FU}(\mu \mathrm{M})$

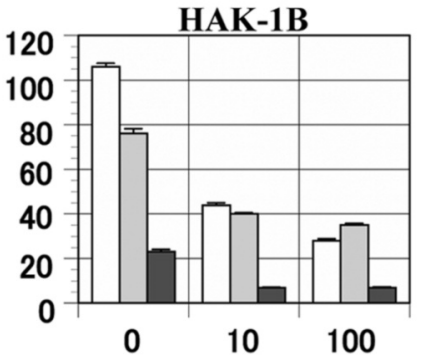

Concentration of $-5 \mathrm{FU}(\boldsymbol{\mu M})$

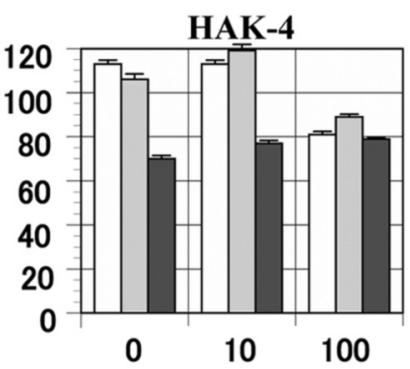

Concentration of $-5 \mathrm{FU}(\boldsymbol{\mu M})$

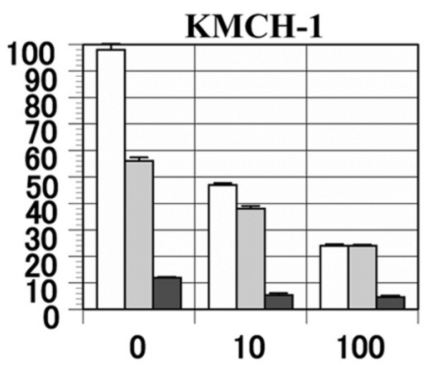

Concentration of $-5 F U(\mu M)$

Figure 3. Effects of quercetin or quercetin+5-FU on the growth of 13 cell line aftertreatment for 72 h. The experiment was repeated at least three times for each cell line to confirm reproducibility of the data, and almost identical results were obtained. Error bar represents SE. 
dose-dependent $\mathrm{G}_{0} / \mathrm{G}_{1}$ phase cell cycle arrest was observed in 4 cell lines (HAK-3, HAK-6, KMCH-1, KMCH-2), in the $\mathrm{G}_{2} / \mathrm{M}$ phase in 6 cell lines (KYN-2, KYN-3, HAK-1B, HAK-2, HAK-4, HAK-5), and in the $S$ phase in 2 cell lines (KIM-1, KYN-1) (Figure 2).

The combination treatment of quercetin and 5-FU produced additional or synergic effects in 9 cell lines (KIM1, KYN-2, KYN-3, HAK-1B, HAK-2, HAK-5, HAK-6, $\mathrm{KMCH}-1, \mathrm{KMCH}-2$ ) (Figure 3).

\section{Discussion}

Quercetin induced a dose-dependent and time -dependent antiproliferative effect in most of the 13 cell lines, and a certain degree of apoptosis in all 13 cell lines. The liver cancer cell lines used in this study had been established from different types of liver cancers, including well to poorly differentiated HCC, sarcomatous HCC, and combined hepatocellular and cholangiocarcinoma. The fact that potent growth inhibition was observed in cell lines of different histology should be emphasized. Although in vitro antiproliferative findings may not exactly resemble those in clinical applications, these findings indicate that quercetin may be efficacious in the treatment of various types of HCC. Experimental reports thus far indicate that quercetin activates caspases, which are involved in the induction of apoptosis, and has an inhibitory effect on the PI3K/Akt and ERK pathways (20). It is possible that the liver cancer cell lines used in this study may have undergone apoptosis and cell growth inhibition by similar mechanisms.

Even though our results on the cell cycle arrest induced by quercetin indicated that most liver cancer cell lines underwent cell cycle arrest, the arrest phase varied from cell line to cell line. Of the 13 liver cancer cell lines studied, 4 cell lines underwent cell cycle arrest in the $G_{0} / G_{1}$ phase, 2 cell lines in the $S$ phase, and 6 cell lines in the $G_{2} / M$ phase. This is similar to cell cycle arrest by quercetin as reported previously, where the arrest has been shown to take place at different points of the cell cycle (21-23). Quercetin may be able to induce $G_{0} / G_{1}$ phase, $G_{2 /} M$ phase and $S$ phase cell cycle arrest, depending on the type of liver cancer cell line. Further research is needed to determine the exact mechanism.

Treatment with the combination of quercetin and 5-FU led to enhanced growth inhibition in some cell lines, compared to when quercetin was administered on its own. This result was similar to previous reports by Dai et al. demonstrating that 5-FU enhanced quercetin's inhibition of cell growth in vitro and in vivo (24). As the combined use of quercetin and 5-FU showed additional or synergistic effects relative to the use of quercetin alone, this result suggests that the combined use may inhibit the growth of liver cancer at a greater extent. In conclusion, the present study revealed that quercetin suppressed the proliferation of liver cancer cells via induction of apoptosis and cell cycle arrest. Further investigations are needed to clarify the signalling pathways involved in quercetin-induced apoptosis and proliferation inhibition in liver cancer cells.

\section{Conflicts of Interest}

The Authors declare no conflicts of interest associated with this manuscript.

\section{Authors' Contributions}

Toru Hisaka designed the study, and wrote the initial draft of the manuscript. Toru Hisaka and Hisamune Sakai contributed to analysis and interpretation of data, and assisted in the preparation of the manuscript. All other Authors have contributed to data collection and interpretation, and critically reviewed the manuscript. All Authors approved the final version of the manuscript, and agreed to be accountable for all aspects of the work in ensuring that questions related to the accuracy or integrity of any part of the work are appropriately investigated and resolved.

\section{Acknowledgements}

The Authors are grateful to Ms Akemi Fujiyoshi, Ms Mika Hanada and Ms Atsuko Matsuo for their assistance in the experiments.

\section{References}

1 Forner A, Reig M and Bruix J: Hepatocellular carcinoma. Lancet 391(31): 1301-1314, 2019. PMID: 29307467. DOI: 10.1016/S01406736(18)30010-2

2 Bréchot C, Jaffredo F, Lagorce D, Gerken G, Büchenfelde KM, Papakonstoninou A, Hadziyannis S, Romeo R, Colombo M, Rodes J, Bruix J, Williams R and Naoumov N: Impact of HBV, $\mathrm{HCV}$ and $\mathrm{GBV}-\mathrm{C} / \mathrm{HGV}$ on hepatocellular carcinoma in Europe: results of a European concerted action. J Hepatol 29(2): 173-183, 1998. PMID: 9722197. DOI: 10.1016/s0168-8278(98)80001-9.

3 Di Bisceglie AM, Order SE, Klein JL, Waggoner JG, Sjogren MH, Kuo G, Houghton M, Choo QL and Hoofnagle JH: The role of chronic viral hepatitis in hepatocellular carcinoma in the United States. Am J Gastroenterol 86(3): 335-338, 1991. PMID: 1847790 .

4 Shiratori Y, Shiina S, Imamura M, Kato N, Kanai F, Okudaira T, Teratani T, Tohgo G, Toda N and Ohashi M: Characteristic difference of hepatocellular carcinoma between hepatitis B- and C-viral infection in Japan. Hepatology 22(4 Pt 1): 1027-1033, 1995. PMID: 7557847. DOI: 10.1016/0270-9139(95)90605-3.

5 Li Y, Yao J, Han C, Yang J, Chaudhry MT, Wang S, Liu H and Yin Y: Quercetin, inflammation and immunity. Nutrients $8(3)$ : 167, 2016. PMID: 26999194. DOI: 10.3390/nu8030167

6 Singhal RL, Yeh YA, Praja N, Olah E, Sledge GW Jr. and Weber G: Quercetin down-regulates signal transduction in human breast carcinoma cells. Biochem Biophys Res Commun 208(1): 425431, 1995. PMID: 7887960. DOI: 10.1006/bbrc.1995.1355

7 Nguyen TT, Tran E, Nguyen TH, Do PT, Huynh TH and Huynh $\mathrm{H}$ : The Role of Activated MEK-ERK pathway in quercetin- 
induced growth inhibition and apoptosis in A549 lung cancer cells. Carcinogenesis 25(5): 647-659, 2004. PMID: 14688022. DOI: $10.1093 /$ carcin/bgh052

8 Zhang W, Yin G, Dai J, Sun YU, Hoffman RM, Yang Z and Fan $Y$ : Chemoprevention by quercetin of oral squamous cell carcinoma by suppression of the NF- $x \mathrm{~B}$ signaling pathway in DMBA-treated hamsters. Anticancer Res 37(8): 4041-4049, 2017. PMID: 28739686. DOI: 10.21873/anticanres.11789

9 Mokbel K, Wazir U and Mokbel K: Chemoprevention of prostate cancer by natural agents: evidence from molecular and epidemiological studies. Anticancer Res 39(10): 5231-5259, 2019. PMID: 31570421. DOI: 10.21873/anticanres. 13720

10 Yano H, Iemura A, Haramaki M, Ogasawara S, Takayama A, Akiba $J$ and Kojiro M: Interferon alfa receptor expression and growth inhibition by interferon alfa in human liver cancer cell lines. Hepatology 29(6): 1708-1717, 1999. PMID: 10347112. DOI: $10.1002 /$ hep.510290624

11 Murakami T: Establishment and characterization of human hepatoma cell line (KIM-1). Acta hepatol Jpn 25: 532-539, 1984.

12 Yano H, Kojiro M and Nakashima T: A new human hepatocellular carcinoma cell line $(\mathrm{KYN}-1)$ with a transformation to adenocarcinoma. In Vitro Cell Dev Biol 22(11): 637-646, 1986. PMID: 2430933. DOI: 10.1007/bf02623477

13 Yano H, Maruiwa M, Murakami T, Fukuda K, Ito Y, Sugihara S and Kojiro M: A new human pleomorphic hepatocellular carcinoma cell line, KYN-2. Acta Hepatol Jpn 38: 953-966, 1988.

14 Murakami T, Maruiwa M, Fukuda K, Kojiro M, Tanaka M and Tanikawa K: Characterization of new human hepatoma cell line (KYN-3) derived from the ascites of the hepatoma patient [Abstract]. Proceedings of Japanese Cancer Association. Jpn J Cancer Res 292, 1988.

15 Yano H, Iemura A, Fukuda K, Mizoguchi A, Haramaki M and Kojiro M: Establishment of two distinct human hepatocellular carcinoma cell lines from a single nodule showing clonal dedifferentiation of cancer cells. Hepatology 18(2): 320-327, 1993. PMID: 8393423.

16 Haramaki M, Yano H, Iemura A, Momosaki S, Ogasawara S, Inoue M, Yamaguchi R, Kusaba A, Utsunomiya I and Kojiro M: A new human hepatocellular carcinoma cell line (HAK-2) forms various structures in collagen gel matrices. Hum Cell 10(3): 183192, 1997. PMID: 9436038

17 Murakami T, Yano H, Maruiwa M, Sugihara S and Kojiro M: Establishment and Characterization of a human combined hepatocholangiocarcinoma cell line and its heterologous transplantation in nude mice. Hepatology 7(3): 551-556, 1987. PMID: 3032760. DOI: 10.1002/hep.1840070322
18 Yano H, Iemura A, Haramaki M, Momosaki S, Ogasawara S, Higaki K and Kojiro M: A human combined hepatocellular and cholangiocarcinoma cell line (KMCH-2) that shows the features of hepatocellular carcinoma or cholangiocarcinoma under different growth conditions. J Hepatol 24(4): 413-422, 1996. PMID: 8738727. DOI: 10.1016/s0168-8278(96)80161-9

19 Yano H, Mizoguchi A, Fukuda K, Haramaki M, Ogasawara S, Momosaki S and Kojiro M: The herbal medicine Sho-Saiko-To inhibits proliferation of cancer cell lines by inducing apoptosis and arrest at the $\mathrm{G}_{0} / \mathrm{G}_{1}$ phase. Cancer Res 54(2): 448-454, 1994. PMID: 8275481.

20 Granado-Serrano AB, Martín MA, Bravo L, Goya L and Ramos $\mathrm{S}$ : Quercetin induces apoptosis via caspase activation, regulation of Bcl-2, and inhibition of PI-3-kinase/Akt and ERK pathways in a human hepatoma cell line (HepG2). J Nutr 136(11): 27152721, 2019. PMID: 17056790. DOI: 10.1093/jn/136.11.2715

21 Srisa-Nga K, Mankhetkorn S, Okonogi S and Khonkarn R: Delivery of superparamagnetic polymeric micelles loaded with quercetin to hepatocellular carcinoma cells. J Pharm Sci 108(2): 996-1006, 2019. PMID: 30121312. DOI: 10.1016/j.xphs.2018. 08.008

22 Pi J, Li B, Tu L, Zhu H, Jin H, Yang F, Bai H, Cai H and Cai J: Investigation of Quercetin-induced HepG2 cell apoptosisassociated cellular biophysical alterations by atomic force microscopy. Scanning 38(2): 100-112, 2016. PMID: 26179807. DOI: $10.1002 /$ sca.21245

23 Sudan S and Vasantha Rupasinghe Hp: Antiproliferative activity of long chain acylated esters of quercetin-3-O-glucoside in hepatocellular carcinoma HepG2 cells. Exp Biol Med 240(11): 1452-1464, 2015. PMID: 25681471. DOI: 10.1177/153537021 5570828

24 Dai W, Gao Q, Qiu J, Yuan J, Wu G and Shen G: Quercetin induces apoptosis and enhances 5-fu therapeutic efficacy in hepatocellular carcinoma. Tumour Biol 37(5): 6307-6313, 2016. PMID: 26628295. DOI: 10.1007/s13277-015-4501-0 